\title{
BIOSISTEMATIK SPECIES Annona muricata, Annona squamosa DAN Annona reticulata DENGAN PENDEKATAN ALKALOID
}

\author{
Hamidah*, Santoso**, Rina Kasiamdari** \\ *Departemen Biologi, Fakultas Sains dan Teknologi, Universitas Airlangga \\ **Fakultas Biologi, Universitas Gadjah Mada
}

\begin{abstract}
This research aimed to explore kinship Annona muricata, Annona squamosa and Annona reticulata on the basis alkaloid content. Study phenotype Annona muricata, Annona squamosa and Annona reticulata based alkaloid content. Data alkaloid obtained are then processed by a computer program SPSS version 14. The results of this study indicate that the presence of variations in the character of the three types of Annona of species alkaloid. From the data analysis it can be seen that there are differences in the variations that occur in Annona muricata, Annona squamosa and Annona reticulata by different habitats and is a variation of phenotypic variation. Dendrogram grouping results suggest that Annona squamosa and Annona reticulata fenetic ties closer, so clumped into one large group while Annona muricata Annona split away from the other groups.
\end{abstract}

Keywords: characterization, alkaloids, fenetic, Annona Spp.

\section{PENGANTAR}

Klasifikasi Annonaceae dari famili hingga spesies telah dinyatakan mantap (Watson \& Dalwitz, 1992; Backer and Bakhuizen, 1963). Annonaceae merupakan anggota ordo Ranales yang merupakan anggota Magnoliopsida primitif dengan bercirikan bagian-bagian bunga tersusun spiral (anggota yang maju tersusun siklis). Spesies Annona yang terdapat di muka bumi antara lain: Annona muricata L., Annona squamosa L., Annona cherimola L., Annona reticulata L., Annona diversifolia L., Annona purpurea L., Annona glabra L., dan Annona montana L. (Samson, 1986). Sedangkan Annona yang dapat dijumpai di Indonesia, yaitu: A. muricata, A. squamosa, dan A. reticulata. A. muricata dan A. squamosa pada saat ini masih sering ditemukan bila dibandingkan dengan jenis $A$. reticulata. Hal ini karena kedua jenis tersebut sering dijumpai dengan jenis A. reticulata. Hal ini karena banyak dibudidayakan untuk dimanfaatkan buahnya. Sedangkan A. reticulata merupakan salah satu anggota Annonaceae yang mulai sulit dijumpai (langka), bila dibandingkan dengan A. muricata dan A. squamosa. A. reticulata tidak banyak ditanam karena masyarakat kurang menyukai rasa buahnya dan jumlah buahnya sedikit. Apabila tidak mendapatkan perhatian khusus, tidak mustahil akan punah (Ashari, 1995).

Habitat merupakan tempat tumbuh suatu organisme. Habitat yang berbeda akan mempengaruhi kehidupan organisme antara lain proses fisiologi dan karakter morfologi, bahkan pada kondisi ekstrem dapat mempengaruhi karakter genetik. Berdasarkan hasil pendahuluan yang telah dilakukan dalam penelitian ini A. muricata pada habitat yang berbeda menunjukkan adanya keanekaragaman yang menyolok seperti pada ukuran daun, bangun daun, dan warna daun. Fenomena ini juga dijumpai pada $A$. squamosa, dan $A$. reticulata.

Penelitian yang telah dilakukan selama ini pada Annona adalah tentang peran atau manfaat kandungan bioaktif Annona antara lain oleh de Feo (1992), Bories et al., (1991), dan Lopes-Abraham et al. (1979). Penelitian tentang kekerabatan Annona secara morfologi ataupun molekular telah dilakukan oleh Royero et a.l., 2004, yaitu penelitian tentang kekerabatan variasi morfologi $A$. muricata yang hidup pada tempat yang berbeda di Colombia dengan teknik Random Amplified Polymorphic DNA (RAPD) dan penelitian kekerabatan A. muricata dan A. cherimolia secara molekular dengan teknik RAPD (Bridg, 2005). Penelitian tentang hubungan kekerabatan fenetik antara A. muricata, A. squamosa, dan $A$. reticulata belum didapatkan.

Berdasarkan latar belakang tersebut di atas, maka perlu dilakukan penelitian untuk menjawab permasalahan mengenai hubungan kekerabatan fenenetik dari A. muricata, A. squamosa, dan A. reticulata berdasarkan kandungan alkaloid dan faktor-faktor apa yang mempengaruhi pengelompokan tersebut yang hidup di daerah Surabaya dan Pacitan. Analisis numerik merupakan analisis yang dapat membantu memecahkan permasalahan data kualitatif dan kuantitatif kandungan alkaloid \& flavonoid, (Chandler \& Crisp, 1998). 


\section{BAHAN DAN DAN CARA KERJA}

\section{Bahan}

Bahan penelitian yang digunakan adalah daun dari tiga jenis Annona, yaitu Annona muricata, Annona squamosa, dan Annona reticulata yang hidup di Pacitan dan Surabaya.

Bahan kimia yang digunakan berderajat p.a (pro analisis), meliputi:

a. Bahan untuk ekstraksi adalah methanol, bahan untuk fraksinasi, yaitu: natrium hidroksida, etil asetat, nheksana, magnesium anhidrat, asam sitrat 5\%, diklorometana, bahan untuk kromatografi lapis tipis (KLT), yaitu lembar silika gel G Merck TA899231130, lembar selulosa mutu analisis dari Avicell 394032, ammonium hidroksi pekat, sikloheksana, kloroform, dietilamina, toluena, etil asetat, metanol, benzena, dietil asetat, tersier butanol, asam asetat glasial, air, asam asetat $15 \%$.

b. Bahan untuk kromatografi kolom yaitu n-heksana, aseton, metanol, kloroform, Bahan pereaksi penampak bercak adalah pereaksi Dragendorff modifikasi Munier, aluminium klorida, ammonia, serium sulfat $1 \%$ dalam asam sulfat $1 \mathrm{M}$.

\section{Cara kerja}

1. Dilakukan skrining alkaloid serbuk daun sampel Annona muricata, A. squamosa, dan A. reticulata,

2. Dilakukan ekstraksi dan isolasi senyawa alkaloid dan dilakukan identifikasi alkaloid. Senyawa alkaloid yang diperoleh dari proses pemisahan kromatografi kolom cepat, untuk selanjutnya dilakukan kromatografi lapis tipis (KLT) dengan fase gerak yang telah ditentukan terlebih dahulu yaitu sikloheksana - kloroform - dietilamina (5:4:1), sikloheksana - dietilamina (9:1), toluena - etil asetat - dietilamina (7:2:1), kloroform - metanol (5:1), kloroform - dietilamina (9:1), benzena - dietil asetat - dietil amina (7:2:1), dan fase diam silika gel.

Masing-masing bercak yang diperoleh dihitung hRfnya dan warna bercak pada lampu UV $365 \mathrm{~nm}$. Pengamatan warna bercak dilakukan di atas lampu UV $365 \mathrm{~nm}$, warna bercak untuk dapat dianalisis harus dikonversikan dengan nilai indeks warna RGB (Red-Green-Blue Index) untuk spektrum tampak pada fotografi. Langkah selanjutnya, lempeng KLT disemprot dengan pereaksi Dragendorff. Warna bercak yang berwarna coklat kemerahan dan muncul pada lempeng KLT paling sedikit tiga kali fase gerak yang didata dan dianalisis.

\section{ANALISIS DATA}

Data yang diperoleh berupa nilai hRf dan warna bercak pada UV $365 \mathrm{~nm}$ senyawa alkaloid dibandingkan dengan data nilai hRf dan warna bercak pada UV $365 \mathrm{~nm}$ senyawa alkaloid dari buku acuan Baerheim-Svendsen dan Verpoorte (1983) yang memiliki sistem KLT sama sebagai referensi.

Data nilai hRf dan warna bercak pada UV $365 \mathrm{~nm}$ senyawa alkaloid tersebut. Kemudian dikelompokkan dengan metode analisis gugus program SPSS dan menggunakan jarak ketidakmiripan Euclidean untuk sampel pengelompokan nilai hRf dan warna bercak pada UV $365 \mathrm{~nm}$ senyawa alkaloid sampel dibandingkan dengan nilai hRf dan warna bercak pada UV $365 \mathrm{~nm}$ senyawa alkaloid acuan. Kelompok senyawa segugus yang terbentuk diidentifikasi sebagai senyawa yang segolongan.

\section{HASIL}

Dari hasil penelitian didapatkan data yang ditampilkan pada Tabel 1.

Tabel 1. Jenis-Jenis alkaloid pada tanaman sampel spesies Annona muricata, Annona squamosa, dan Annona reticulata

\begin{tabular}{llc}
\hline Spesies & Jenis Alkaloid terkandung & Nomer Bercak \\
\hline AMS & Benzylisoquinolin & AMS24c \\
& Indol alkaloid I & AMS34a \\
& Isoquinolin & AMS45a \\
\hline AMP & Indol alkaloid I & AMP23a \\
& Indol alkaloid II & AMP54b \\
& Indol alkaloid III & AMP24c \\
& Indol alkaloid IV & AMP65b \\
& Quinolin alkaloid & AMP352 \\
\hline ASS & Indol alkaloid I & ASS 21c \\
& Indol alkaloid II & ASS62d \\
& Indol alkaloid III & ASS43b \\
& Indol alkaloid IV & ASS221 \\
\hline ASP & Indol alkaloid I & ASP33f \\
& Indol alkaloid II & ASP53c \\
\hline ARS & Indol alkaloid I & ARS64a \\
& Indol alkaloid II & ARS25a \\
\hline ARP & Indol alkaloid I & ARP63c \\
& Isoquinolin & ARP631 \\
\hline
\end{tabular}

Keterangan:

AMS = Annona muricata dari Surabaya

AMP = Annona muricata dari Pacitan

ASS = Annona squamosa dari Surabaya

ASP = Annona squamosa dari Pacitan

ARS = Annona reticulata dari Surabaya

ARP = Annona reticulata dari Pacitan 


\section{PEMBAHASAN}

Nilai hRf dan kode warna dianalisis dengan data jenisjenis alkaloid dari pustaka acuan Baerheim-Svendsen dan Verpoorte (1983) sebagai pembanding. Senyawa alkaloid yang terkelompok dalam gugus yang berdekatan, dianggap mewakili satu kelompok senyawa alkaloid. Nampak pada hasil penggugusan bahwa bercak-bercak kromatogram dari sampel penelitian memiliki kedekatan sifat yang diwakili oleh senyawa alkaloid benzilisokuinolin, boldnina, ergot, serpentina, quinine, dan papaverina.

Merujuk pada Yu et al. (1998) bahwa kebanyakan alkaloid pada marga Annona yang memiliki kedekatan sifat dengan alkaloid bensizilisokuinolin. Berdasarkan analisis karakter kandungan alkaloid yang diperoleh pada Tabel 1, maka variasi-variasi tersebut dapat dihitung nilai koefisien kesamannya. Pada spesies Annona muricata dari Surabaya dan Pacitan didapatkan nilai koefisien kesamaan sebesar 0,818 (garis fenon 81,8\%). Spesies Annona squamosa dari Surabaya dan Pacitan mempunyai nilai indeks kesamaan sebesar 0,909 (garis fenon 90,9\%). Sedangkan Annona reticulata dari Surabaya dan Pacitan mempunyai nilai koefisien kesamaan 0,818 (garis fenon $81,8 \%$ ). Nilai koefisien kesamaan ketiga spesies tersebut dapat dilihat pada Tabel 2.

Nilai ketiga koefisien kesamaan kandungan alkaloid yang terkandung tersebut menyatakan bahwa Annona muricata dari Surabaya dan Pacitan merupakan satu spesies; Annona squamosa dari Surabaya dan Pacitan merupakan satu spesies; dan Annona reticulata dari Surabaya dan Pacitan merupakan satu spesies. Hal ini sesuai dengan pendapat Singh (1999) yang menyatakan bahwa pada tingkat kesamaan $85 \%$ (garis phenon $85 \%$ ) tumbuhan dapat digolongkan dalam satu jenis yang sama, pada tingkat kesamaan 65\% (garis phenon 65\%) tumbuhan dapat digolongkan dalam satu marga yang sama, pada tingkat kesamaan 45\% (garis phenon 45\%) tumbuhan dapat digolongkan dalam satu suku yang sama.

Pengelompokan ketiga Annona dilakukan dengan menggunakan analisis gugus dan sebagai pelengkap digunakan analisis komponen utama. Analisis gugus dilakukan berdasarkan pengukuran kesamaan antar satuan taksonomi operasional (STO) dengan menggunakan koefisien simple matching untuk data biner. Pengukuran tersebut didasarkan pada sebaran kandungan senyawa alkaloid dari ketiga Annona yang disusun pada Tabel 3 dengan analisis classify hierarchical cluster.

Tabel 2 tersebut disusun berdasarkan sebaran senyawa alkaloid dari ketiga Annona yang tersaji pada Tabel 3. Dari Tabel 3 tersebut nampak bahwa karakter senyawa alkaloid mempunyai pola spesifik, sebagai karakter yang dimiliki bersama.

Tabel 2. Nilai koefisien kesamaan spesies Annona muricata, Annona squamosa, dan Annona reticulata ditinjau dari kandungan alkaloid

\begin{tabular}{ccccccc}
\hline \multirow{2}{*}{ Case } & \multicolumn{7}{c}{ Simple matching Measure } \\
\cline { 2 - 7 } & 1:AMS & 2:AMP & 3:ASS & 4:ASP & 5:ARS & 6:ARP \\
\hline 1:AMS & 1.000 & .818 & .545 & .455 & .364 & .545 \\
2:AMP & .818 & 1.000 & .364 & .273 & .182 & .364 \\
3:ASS & .545 & .364 & 1.000 & .909 & .455 & .636 \\
4:ASP & .455 & .273 & .909 & 1.000 & .545 & .727 \\
5:ARS & .364 & .182 & .455 & .545 & 1.000 & .818 \\
6:ARP & .545 & .364 & .636 & .727 & .818 & 1.000 \\
\hline
\end{tabular}

This is a similarity matrix

Tabel 3. Sebaran kelompok senyawa alkaloid pada Annona muricata, Annona squamosa, dan Annona reticulata

\begin{tabular}{cccccccccccc}
\hline Spesies & Indol 1 & Indol 2 & Indol 3 & Indol 4 & Indol 5 & Indol 6 & Indol 7 & Isoq 1 & Isoq 2 & benzilisoq & Quino \\
\hline AMS & 0 & 0 & 0 & 0 & 1 & 0 & 0 & 1 & 0 & 1 & 0 \\
AMP & 0 & 0 & 1 & 1 & 1 & 0 & 1 & 1 & 0 & 1 & 1 \\
ASS & 1 & 1 & 0 & 0 & 1 & 0 & 1 & 0 & 0 & 0 & 0 \\
ASP & 1 & 0 & 0 & 0 & 1 & 0 & 0 & 0 & 0 & 0 & 0 \\
ARS & 0 & 0 & 0 & 0 & 0 & 1 & 0 & 0 & 0 & 0 & 0 \\
ARP & 0 & 0 & 0 & 0 & 1 & 0 & 0 & 0 & 1 & 0 & 0 \\
\hline
\end{tabular}


Hasil pengelompokan dengan analisis gugus tergambar dalam dendrogram berikut.

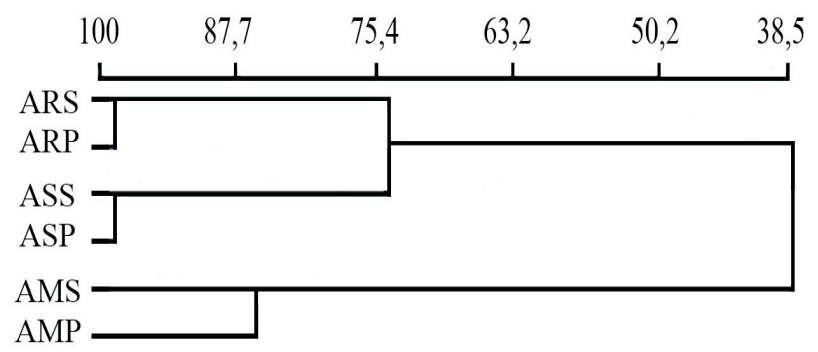

Gambar 1. Dendrogram hasil pengelompokan Annona muricata, Annona squamosa, dan Annona reticulata dengan berdasarkan kandungan alkaloid (Hamidah, 2009)

Keterangan:

AMS = Annona muricata dari Surabaya

AMP = Annona muricata dari Pacitan

ASS = Annona squamosa dari Surabaya

ASP = Annona squamosa dari Pacitan

ARS = Annona reticulata dari Surabaya

ARP $=$ Annona reticulata dari Pacitan

Pada dendrogram nampak bahwa Annona squamosa dan Annona reticulata membentuk satu klaster yang terpisah dengan Annona muricata. Dengan kata lain Annona squamosa mempunyai jarak taksonomi cukup dekat Annona reticulata bila dibandingkan Annona muricata.

Untuk melihat kemantapan hasil pengelompokan pada analisis gugus, terutama untuk melihat bentuk pemisahan ketiga Annona, digunakan analisis komponen utama. Hasil analisis komponen utama ini juga digunakan untuk mengetahui peran setiap karakter setiap karakter alkaloid dalam penyebaran taksa di sepanjang aksis komponen utama. Berikut ini hasil analisis komponen utama pada tanaman Annona muricata, Annona squamosa, dan Annona reticulata yang diteliti.

Hasil analisis komponen utama mengambarkan bahwa Annona muricata terpisah dengan Annona squamosa dan Annona reticulata. Pengelompokan ini menggunakan tiga komponen utama pertama dengan tingkat nilai kumulatif nilai eigen sebesar $90,142 \%$. Karakter senyawa isoquinolin 2 tidak dapat digunakan karena memiliki nilai korelasi negatif. Pemisahan ketiga Annona dalam diagram pencar tersebut pada aksis sumbu komponen utama ditentukan oleh besarnya nilai komponen utama (Tabel 2). Pada sumbu aksis komponen utama pertama, sebaran jenis Annona ditentukan oleh kehadiran senyawa benzyl isoikuinolin, isoquinolin 1, indol 3, 4, dan 7, dan quinolin. Alkaloid isokuinolin 1, quinolin, dan benzylisokuinolin dimiliki Annona muricata. Sedangkan indol 3,4, dan 7 dimiliki oleh Annona squamosa dan Annona reticulata. Pada komponen utama 2 sebaran
Tabel 4. Nilai komponen utama pada tanaman Annona muricata, Annona squamosa, dan Annona reticulata ditinjau dari kandungan alkaloid

\begin{tabular}{lccc}
\hline & \multicolumn{3}{c}{ Komponen Utama } \\
\hline & $\mathbf{1}$ & $\mathbf{2}$ & $\mathbf{3}$ \\
\hline k10 (benzylisoikuinolin) & .957 & & \\
k4 (indol 4) & .957 & & \\
k8 (isoquinolin 1) & .957 & & \\
k7 (indol 7) & .774 & & .587 \\
k11 (quinolin) & .770 & & .587 \\
k3 (indol 3) & .770 & & \\
k1 (indol 1) & & .878 & \\
k2 (indol 2) & & .878 & \\
k9 (isoquinolin 2) & -.587 & -.723 & \\
k6 (indol 6) & & -.718 & \\
k5 (indol 5) & & .718 & \\
\hline
\end{tabular}

jenis Annona ditentukan oleh kehadiran senyawa indol 1,2, dan 5. Pada komponen utama 3 sebaran jenis Annona ditentukan oleh kehadiran senyawa quinolin dan indol 3 yang sama pada komponen utama 1 .

Dilihat dari kehadiran karakter yang berperan pada pemisahan taksa di komponen utama 1, nampaknya kehadiran senyawa benzylisoikuinolin, isoquinolin 1, indol 3, 4, dan 7, dan quinolin dari Annona muricata lebih berperan penting dibandingkan kehadiran senyawa alkaloid lainnya. Dapat pula dikatakan bahwa pemisahan Annona muricata dengan Annona squamosa dan Annona reticulata ditentukan oleh senyawa benzylisoikuinolin, isoquinolin 1 , indol 3, 4, dan 7, dan quinolin.

\section{KEPUSTAKAAN}

Ashari, S. 1995. Hortikultura Aspek Budaya. Universitas Indonesia. Jakarta.

Backer, C.A., and van den Brink Bakhuizen, 1963. Flora of Java. Volume I. Angiospermae. N.V.P. Noodhroff-Groningen-the Netherlands. p 100-116.

Baerheim-Svendsen, dan Verpoorte, C. 1983. Chromatography of Alkaloid. Elsevier Sci. Pub. Company. The Nedherlands. p: 3-49; 171-220.

Bories, C., P. Loiseau, D. Cortes, S.H. Myint; dan R. Hocquemiller, 1991. Antiparasitic activity of Annona muricata and Annona cherimola seeds. Planta Med. 57: 434-436.

Bridg, H. 2005. Citing Computer References; Annona: Micropropagation and determination of the in vitro stability of Annona cherimola Mill and Annona muricata.L. http:// www.google.com/DNA (Access 23 Januari 2005).

Chandler, G.T., dan M.D. Crips, 1998. Morphometric and philogenetic Analysis of The Deviesia ulicifolia complex (Fabaceae, Mirbeliaceae). Pl.Syst.Evol.209: 93-122. 
de Feo, V. 1992. Plantas Medicinale Y Magicas del norte de Los Andes Perunanas. Fitoterapia. 63: 417-440.

Lopesz-Abraham, A.M., Rojas, N.M., dan Jimenes, C.A. 1979. Plant extracs with cytostatic properties growing in Cuba. Rev.Cubana Med Trop, 31: 97-104.

Samson, J.A. 1986. Tropical Fruits, $2^{\text {nd }}$ edt Longman Singapore Publisher ltd. Singapore. p: 275-279.

Singh, G. 1999, Plant Systematics. Science Publishers Inc., USA. p: 1, 181-187.

Royero, N., Jimenez, A.V., Gallego, G., Saavedra, R., Cabra, J., dan Tohme, J. 2004. Citing Computer References, Annona: Molecular and Agro-morphological Characterization of the Genetic Variability of Soursop (Annona muricata L) Accesion and related Annonaceus Species http://www. google.com/DNA (Access 23 Januari 2005).

Watson, L dan Dalwitz, M.J. 1992, The Families of Flowering Plants: Descriptions, Illustrations, Identification and Information Retrieval, version 19th August 1999, http// www.biodiversity.uno. edu/delta/angio/www/annonace. htm.

Yu, J.G., Wu, F.E., Luo, X.Z, dan Sun, L. 1998 Murihexol, a linear acetogenin from Annona muricata, Phytochemistry 49: 1689-1692. 